\title{
Spatio-temporal variation of Mocis latipes (Guenée, 1852) (Lepidoptera: Erebidae) populations in Brazil according to meteorological factors
}

\author{
Vander C. M. Claudino ${ }^{I}$, Alexandre Specht ${ }^{2}{ }^{\circledR}$, Elisangela G. Fidelis ${ }^{2}$, Vânia F. Roque-Specht ${ }^{1}$, Débora G. \\ Montezano ${ }^{3}$, Pedro R. Martins ${ }^{1}$, Fernando A. M. Silva ${ }^{2}$ \& Juaci V. Malaquias ${ }^{2}$ \\ ${ }^{1}$ Universidade de Brasília, Faculdade UnB Planaltina, Área Universitária $n^{\circ}$ 1, Vila Nossa Senhora de Fátima, \\ CEP 73345-010, Planaltina, DF, Brasil. \\ ${ }^{2}$ Embrapa Cerrados, BR 020, Km 18, Caixa Postal 08223, CEP 73310-970, Planaltina, Distrito Federal, Brasil. \\ ${ }^{3}$ Corteva Agrisciense, Marion IA, 52302, USA. \\ *Corresponding author: Alexandre Specht, e-mail: alexandre.specht@embrapa.br
}

CLAUDINO, V.C.M, SPECHT, A., FIDELIS, E.G, ROQUE-SPECHT, V.F., MONTEZANO D.G., MARTINS, P.R., SILVA, F.A.M, JUACI V. MALAQUIAS, J.V. Spatio-temporal variation of Mocis latipes (Guenée, 1852) (Lepidoptera: Erebidae) populations in Brazil according to meteorological factors. Biota Neotropica 21(1): e20201114. https://doi.org/10.1590/1676-0611-BN-2020-1114

\begin{abstract}
Mocis latipes (Guenée, 1852) (Lepidoptera: Erebidae) has been recognized as a major owlet caterpillar associated to the herbivory of gramineaceous plants across the American continent. During outbreaks, the caterpillars are capable of completely consuming preferred hosts (grasses) and, when these hosts are destroyed, they can move to adjacent non-grass plants and cause similar damage. Meteorological variable such as temperature and humidity are described as factors that affect the development and abundance of $M$. latipes. This paper aimed to describe and compare the spatial and temporal distribution of $M$. latipes in different locations in Brazil and to evaluate the influence of meteorological variables on the temporal range. A total of 12 locations were evaluated, in each collection point light traps were installed near cultivated areas. In order to understand the influence of meteorological variables on the abundance of $M$. latipes, the data were analyzed using a Generalized Linear Model according to Poisson regression. A linear regression was also used to verify the relation between the abundance and the latitude. A total of 1,985 moths were collected. The highest collections were in Amazon and Cerrado biomes. Results show that abundance was inversely related to increasing latitude and Poisson regression analysis indicated that the main meteorological variables were significantly related to abundance at each site. This study shows that due to the high preference for gramineas and the high temperature requirements $\left(30^{\circ} \mathrm{C}\right), M$. latipes is an important species in hot regions and regions with hight humidity. Furthurmore, even in higher latitudes, in subtropical areas, during summer months, populations can Rapidly growth being able to cause economic damages.
\end{abstract}

Keywords: light trap; owlet moth pest; populational variations; striped grassworm.

\section{Variações espaço-temporais das popupações de Mocis latipes (Guenée, 1852) (Lepidoptera: Erebidae) no Brasil de acordo com fatores meteorológicos.}

\footnotetext{
Resumo: Mocis latipes (Guenée, 1852) (Lepidoptera: Erebidae) tem sido reconhecida como uma das principais espécies consumidoras de gramíneas em todo o continente americano. Durante os surtos, as lagartas são capazes de consumir completamente os hospedeiros preferenciais (gramíneas) e, quando os hospedeiros preferenciais são destruídos, podem mover-se para plantas adjacentes não gramíneas e causar danos semelhantes. Variáveis meteorológicas, como temperatura e umidade, são conhecidas por afetar o desenvolvimento e a abundância de suas populações. Este trabalho teve como objetivo descrever e comparar a distribuição espaço-temporal de M. latipes em diferentes localidades do Brasil e avaliar a influência de variáveis meteorológicas sobre suas variações temporais. Foram avaliados 12 locais, em cada ponto de coleta foram instaladas armadilhas luminosas próximas às áreas de cultivo. Para entender a influência das variáveis meteorológicas na abundância de $M$. latipes, os dados foram analisados pelo Modelo Linear Generalizado, empregando a regressão de Poisson. Uma regressão linear também
} 
foi utilizada para verificar a relação entre a abundância e a latitude. Um total de 1.985 mariposas foram coletadas. Os maiores números de indivíduos foram coletados nos biomas Amazônia e Cerrado. Os resultados mostram que a abundância de mariposas está inversamente relacionada ao aumento da latitude. A análise de regressão de Poisson indicou que as principais variáveis meteorológicas foram significativamente relacionadas à abundância em cada local. Este estudo mostra que devido à preferência por gramíneas em estado vegetativo e às altas exigências de temperatura $\left(30^{\circ} \mathrm{C}\right)$, M. latipes é uma espécie importante em regiões quentes, especialmente nas épocas de maior umidade. Além disso, mesmo em latitudes elevadas, durante os meses de verão, as populações podem aumentar rapidamente, podendo causar danos econômicos.

Palavras-chave: armadilha luminosa; noctuoides-praga; variações populacionais; curuquerê-dos-capinzais.

\section{Introduction}

Mocis latipes (Guenée, 1852) (Lepidoptera: Erebidae) is an important grass pest that occurs throughout the Americas, from Canada to Argentina, Chile and Uruguay (Bethune 1869, Biezanko et al. 1957, Barth 1958, Angulo \& Jana-Sáenz 1983, Pastrana 2004, Wagner et al. 2011, Alves et al. 2019). Due to the fact that M. latipes is widely distributed, it is common for it to receive different names across its range of distribution. For example, in North America it is called as "striped grassworm" and "striped grass looper" (Genung \& Allen Jr. 1974, Reinert 1975, Koehler et al. 1977); in Central America, "falso medidor de los pastos" and "Guinea-grass moth" (Fennah 1947, Calderón et al. 1981); in Brazil "curuquerê-dos capinzais" and "lagarta-dos-capinzais" (Pigatti \& Mello 1960, Cavalcante 1977, Silva et al. 1991, Correia et al. 1999), in Colombia "gusano agrimensor" (Alvarez-R \& Sanchez-G 1981) and in Argentina "gusano cuarteador" (Costilla et al. 1973, Hayward 1960, Salvatore \& Willink 2004, Acosta et al. 2005).

Although some authors consider M. latipes as a polyphagous pest (e.g. Fonseca \& Autuori 1932, Bissell 1940, Biezanko et al. 1957, 1974, Hayward 1960, Labrador 1964, Kimball 1965, Silva et al. 1968, Costilla et al. 1973, Ware 1973, Bertels 1975, Kleyla et al. 1979, Pastrana 2004, Formentini et al. 2015), the main host plants of M. latipes are grasses. Ogunwolu \& Habeck (1975) has shown that the first to fourth instar larvae are unable to complete their life cycle in non-grassy plants. Despite that, $M$. latipes can be considered a polyphagous species because it has also been collected from non-grassy plants (Ogunwolu $\&$ Habeck 1975) or, after caterpillars completely consume grasses or when selective herbicides are used, they are able to migrate and defoliate other crops (Capinera 2005).

The importance of $M$. latipes as a pest is highlighted due to reports of population outbreaks (e.g. Watson 1933, Pugliese 1954, Capriles \& Ferrer 1973, Reinert 1975, Minno \& Snyder 2008) and its extensive damage to the main cultivated Poaceae, including grains, such as corn, rice, sorghum and wheat (Bodkin 1914, Hempel 1914, 1920a, 1920b, Costa 1944a, 1944b, Fonseca 1944, Bertels \& Rocha 1950, Dinther 1955, Falanghe \& Dias Netto 1961, Hseih 1979, Cruz 1991, Cruz \& Santos 1983, Ferreira 1984, Silva \& Carvalho 1986, Páliz-Sánchez \& Mendonza-Mora 1999, Pitre et al. 1999, Vergara et al. 2001, Hickel et al. 2018), forage crops (Vickery 1924, Lopes 1955, 1961, Labrador 1964, Strayer 1971, Koehler et al. 1977, Calderón et al. 1981, 1982, Costa et al. 1983, Silvain 1984, Silvain \& Dauthuille 1985, Miret 1986, Gibbs 1990, Milán et al. 1990, Silva et al. 1994, Jiménez et al. 1997, Teixeira \& Townsend 1997, Correia et al. 1999, Piedra \& Carrillo 1999, Sánchez Soto \& Ortiz Garcia 1999, Alarcón et al. 2004, Fazolin et al. 2009), and sugar cane (Dine 1913, Wolcott 1921, Holloway 1933, Reiniger 1946,
Queiroz 1965, Mendonça Filho 1972, Costilla et al. 1973, Guagliumi 1973, Mahadeo 1977, Planalsucar 1982, Salvatore \& Willink 2004, Acosta et al. 2005, Salvatore et al. 2009, Marquez 2013).

Usually, M. latipes is reported as a cyclic pest (e.g. Calderón et al. 1981, Saunders et al. 1998) whose abundance is influenced by environmental factors such as humidity, precipitation and temperature (Calderón et al. 1982, Ferreira \& Parra 1985, Gibbs 1990). Therefore, under favorable weather conditions and food availability, their populations increase rapidly.

Temperature and humidity are the main environmental factors that influence occurrence, distribution and complete development of $M$. latipes biological cycle. Therefore, the imbalance of these conditions directly interferes in population size (Bertels 1970, Bernardi et al. 2011). Understanding spatial and temporal distribution of pest species is important to reduce risks of Outbreaks and to develop sustainable management control (Pedigo \& Rice 2009). There is a lack of studies on population dynamics of $M$. latipes in different regions in Brazil. Population outbreaks are known to occur early in the rainy season, especially in the Amazon (Teixeira \& Townsend 1997, Fazolin et al. 2009). However, the factors that cause these occurrences are still unknown. Thus, this paper reports the influence of meteorological variables and latitude on spatio-temporal abundance of $M$. latipes in different regions in Brazil.

\section{Material and Methods}

\section{Moth sampling}

Mocis latipes moths were captured in systematized collections at 12 regions in Brazil (Table 1), being those regions representatives of the main Brazilian biomes and on a latitudinal range $\left(2^{\circ}\right.$ North to $31^{\circ}$ South). At each collection point, a light trap (Light Trap - Bio Controle ${ }^{\circledR}$ ), adapted to Pennsylvania model (Frost 1957), was placed on a pole 3 meters from the ground. Collections were made once a month, from July 2015 to June 2016, during each novilunium repeated for five nights (repetitions). Collection methodology followed Specht et al. (2005) and Piovesan et al. (2018). Traps were placed in areas surrounded by several agricultural crops, especially cotton, soybean, corn and pastures (Table 1). Corn was the only crop presented in all regions.

\section{Mocis latipes identification}

Moths were identified by comparing collected specimens against reference material from the Coleção Entomológica da Embrapa Cerrados (CPAC) and bibliographic resources (Brou Jr., 2004). After 
Table 1. Geographic location, municipality, state, biome, climate (Köppen-Geiger according Beck et al., 2018) and main annual cultures, C cotton, M - maize, S - Soybean, and P - pastures, of each light trap collecting point.

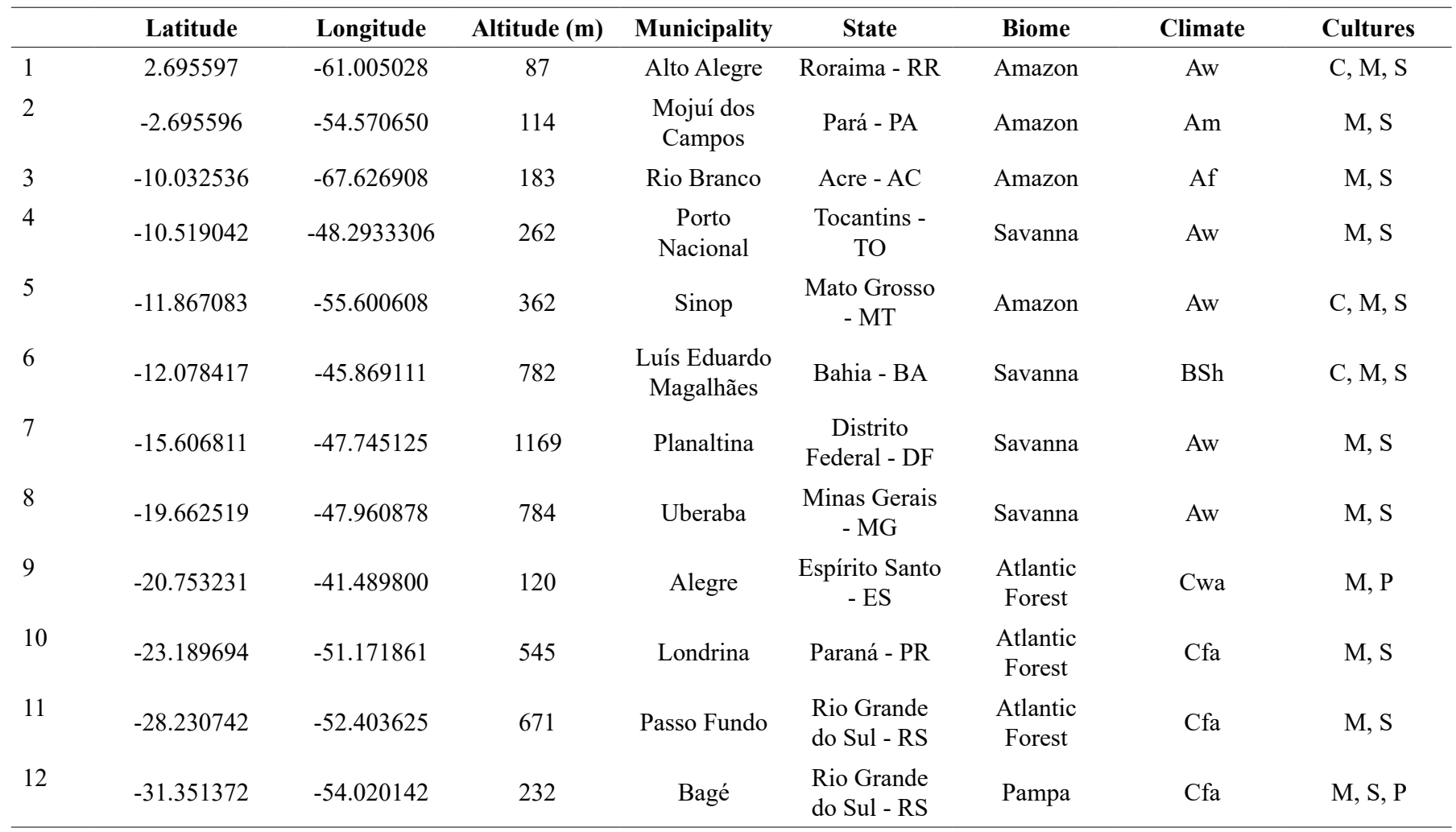

identification, the specimens were stored in glass containers with 92.8GL ethyl alcohol, labeled with date and collecting location. Specimens were kept as voucher material in the CPAC collection and the specific abundance data were tabulated in a spreadsheet for analysis.

\section{Meteorological data}

The meteorological variables considered were the monthly average of the maximum and minimum temperatures $\left({ }^{\circ} \mathrm{C}\right)$, relative humidity $(\%)$ and cumulative precipitation $\left(\mathrm{mm}^{3} / \mathrm{m}^{2} / \mathrm{month}\right)$. The data were obtained from Embrapa Cerrados, Embrapa Agrossilvipastoril, Capixaba Institute for Research, Technical Assistance and Rural Extension - Incaper and National Institute of Meteorology - INMET. Except for data obtained from INMET, all other data were collected at meteorological stations near the sample units.

\section{Statistical analysis}

To evaluate the relationship between the abundance of $M$. latipes and the latitude (Decimal Degrees - DD) used the generalized linear model (GLM) according to Poisson regression with eleven collections points established in the Southern Hemisphere (Table 1). In the same way, as abundance data considers moth count, a GLM Poisson regression was used in order to determine the conjunct influence of meteorological variables on the expected abundance of $M$. latipes at each collecting points. The analysis includes the estimates and respective significance, and the standard errors of the estimate for each collecting point and a general estimate with all points, except for Londrina, Passo Fundo and Bagé, due to the non-significance of the coefficients of the variables when studied individually. The analysis was performed on $\mathrm{R}$ version 3.4.0 (R Development Core Team 2017).

\section{Results}

In total, 1,985 moths of $M$. latipes were collected with greater abundance concentrated in the lower latitudes, in the Amazon and Cerrado biomes. Almost half of the insects (42.11\%) were collected in Alto Alegre-RR, followed by Rio Branco-AC (13.55\%) and Mojuí dos Campos-PA (11.33\%) (Table 2; Figure 1). Moths were found in all sampled locations, most of the year and in 92 collections $(63.88 \%)$ from the 144 collected. Disregarding the southernmost locations (Bagé, Passo Fundo and Londrina), where it is cold during the winter time, $M$. latipes were collected in 84 out of 108 events, which corresponds to more than $3 / 4(77.78 \%)$ of the collections.

The inverse relationship between latitude and abundance of $M$. latipes shown in Figure 1 is statistically confirmed by Poisson regression analysis (Figure 2) whose coefficients were Akaike Information Criterion - AIC 321.780; Intercept: estimate 6.194, SD 0.055, z value $113.100(p>0.001)$ and Latitude: estimate 0.115 , SD 0.004 , $z$ value $25.930(\mathrm{p}>0.001)$.

The monthly occurrence data (Table 2) indicated that, despite occurring in practically the whole year, M. latipes populations varied differently in each location.

Poisson regression analysis indicated for most locations that the conjunct of accumulated monthly precipitation, the monthly averages of minimum and maximum temperature and the monthly average 
Claudino, V.C.M. et al.

Table 2. Monthly abundancy of Mocis latipes moths collected with light traps, during five nights per novilune.

\begin{tabular}{|c|c|c|c|c|c|c|c|c|c|c|c|c|c|c|}
\hline Locality & & & & 2016 & & & & & & 2017 & & & Total & Percent \\
\hline & Jul & Aug & Sep & Oct & Nov & Dez & Jan & Feb & Mar & Apr & May & Jun & & $(\%)$ \\
\hline Alto Alegre - RR & 144 & 531 & 103 & 1 & 0 & 2 & 6 & 2 & 14 & 16 & 17 & 0 & 836 & 42.116 \\
\hline Mojuí dos Campos - PA & 3 & 1 & 3 & 64 & 2 & 14 & 66 & 8 & 4 & 3 & 10 & 47 & 225 & 11.335 \\
\hline Rio Branco - AC & 1 & 1 & 7 & 3 & 12 & 3 & 2 & 2 & 62 & 109 & 39 & 28 & 269 & 13.552 \\
\hline Porto Nacional - TO & 3 & 0 & 0 & 12 & 17 & 9 & 4 & 4 & 32 & 67 & 7 & 2 & 157 & 7.909 \\
\hline Sinop - MT & 1 & 1 & 2 & 3 & 2 & 2 & 2 & 0 & 0 & 0 & 168 & 8 & 189 & 9.521 \\
\hline $\begin{array}{l}\text { Luís Eduardo Magalhães } \\
\text { - BA }\end{array}$ & 0 & 0 & 1 & 1 & 33 & 41 & 25 & 2 & 12 & 8 & 8 & 2 & 133 & 6.700 \\
\hline Planaltina - DF & 0 & 1 & 0 & 0 & 22 & 77 & 1 & 2 & 0 & 1 & 3 & 3 & 110 & 5.542 \\
\hline Uberaba - MG & 0 & 0 & 1 & 0 & 0 & 6 & 0 & 1 & 1 & 3 & 18 & 2 & 32 & 1.612 \\
\hline Alegre - ES & 0 & 2 & 1 & 0 & 1 & 4 & 0 & 0 & 2 & 0 & 0 & 2 & 12 & 0.605 \\
\hline Londrina - PR & 0 & 1 & 0 & 0 & 0 & 0 & 1 & 0 & 0 & 0 & 14 & 1 & 17 & 0.856 \\
\hline Passo Fundo - RS & 0 & 0 & 0 & 1 & 0 & 0 & 1 & 2 & 0 & 0 & 0 & 0 & 4 & 0.202 \\
\hline Bagé - RS & 0 & 0 & 0 & 0 & 0 & 0 & 0 & 0 & 1 & 0 & 0 & 0 & 1 & 0.050 \\
\hline Total & 152 & 538 & 118 & 85 & 89 & 158 & 108 & 23 & 128 & 207 & 284 & 95 & 1985 & 100 \\
\hline
\end{tabular}

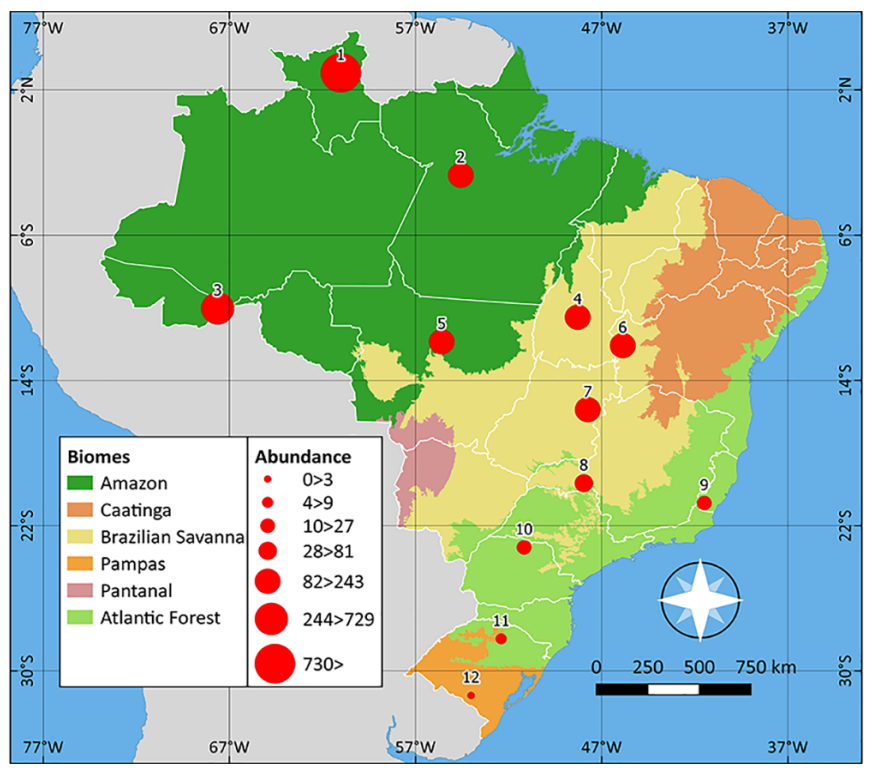

Figure 1. Variation in number (red circles) of Mocis latipes sampled in 12 localities of Brazil (July 2015 - June 2016). For a complete description of localities and dates, see Tables 1-2.

of relative humidity positively influenced abundance (Table 3). As observed between monthly abundance (Table 2), the relations between the number of moths and meteorological variables varied between locations (Table 3 ).

\section{Discussion}

The occurrence of $M$. latipes throughout Brazil (Figure 1) was expected due to the wide distribution previously mentioned in the bibliography (ex. Reinert 1975, Carvalho 1976, Saunders et al. 1998, Bentancourt \& Scatoni 2006, Wagner et al. 2011). The simultaneous occurrence of this species in such a wide and diverse territory is correlated with several biological aspects attributed to insects presenting great geographic distribution that includes: great capacity for dispersion and migration (Ferguson et al. 1991, Brou Jr. 2004, Krauel et al. 2018, Alves et al. 2019), short life cycle with multivoltinism associated with

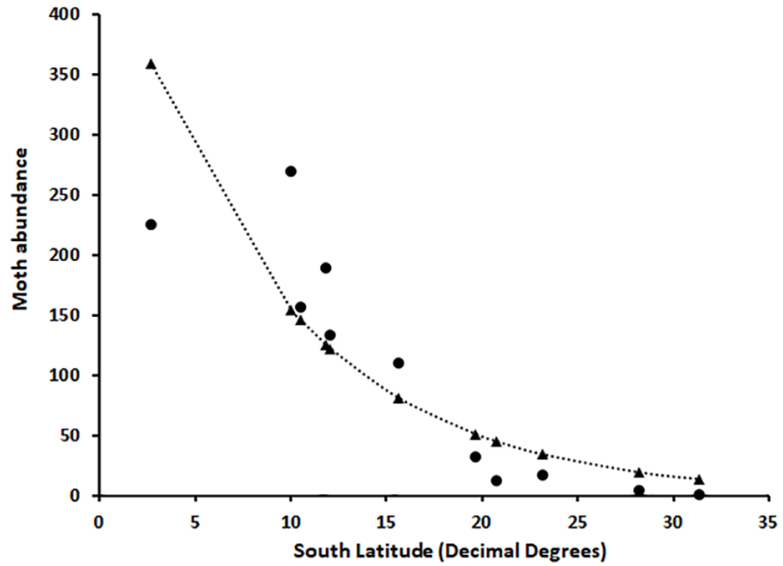

Figure 2. Representation of the observed (circles) and estimated by Poisson regression analysis (triangles) abundance of Mocis latipes in each collection point, according South Latitude.

high fertility (ex. Labrador 1964, Reinert 1975, Cruz \& Santos 1983, Ferreira \& Parra 1985, Silva \& Carvalho 1986, Silva et al. 1991, Piedra \& Carrilo 1999, Wagner et al. 2011), and polyphagy, which allows food to be obtained anywhere and at any time. In this last aspect, $M$. latipes is better classified as an oligophytophage because it develops preferentially in grasses (Ogunwolu \& Habeck 1975) despite consuming other vegetables especially at the end of larval development (Hayward 1960, Labrador 1964, Kimball 1965, Silva et al. 1968, Costilla et al. 1973, Biezanko et al. 1974, Kleyla et al. 1979, Pastrana 2004, Formentini et al. 2015). Despite being an oligophagous, M. latipes has in its favor that grasses are vegetables that have a relatively preserved physical and chemical structure throughout evolutionary history (Kellogg 2001). Thus, this determines that $M$. latipes, like most insects associated with grasses can develop satisfactorily in most species (Tscharntke \& Greiler 1995). Moreover, both annual and perennial grasses are found in almost all environments throughout the year, except for closed forest areas, deserts or very cold regions (Strömberg 2011, Dixon et al. 2014). In addition, cultivated grasses often become invasive, having additional 
Table 3 . Results (AIC - Akaike Information Criterion, Intercept values - Estimate (with significance) and Standard Error -SE) obtained by the Poisson regression analysis between the monthly abundance of Mocis latipes moths collected in each location and the main meteorological variables (Precipitation accumulated in the month; Max. Temp - Average of monthly maximum temperature; Min. Temp - Average monthly minimum temperature and $\mathrm{RH}$ - average monthly relative humidity).

\begin{tabular}{|c|c|c|c|c|c|}
\hline & Intercept & Precipitation & Max. Temp & Min. Temp. & RH \\
\hline \multicolumn{6}{|c|}{ General+ (AIC 4770.80) } \\
\hline Estimate & $-8.898 * * *$ & $0.001 * * *$ & $0.035 \mathrm{~ns}$ & $0.274 * * *$ & $0.058 * * *$ \\
\hline SE & 0.884 & 0.000 & 0.029 & 0.022 & 0.004 \\
\hline \multicolumn{6}{|c|}{ Alto Alegre (AIC 188.35) } \\
\hline Estimate & $34.591 * * *$ & $0.001 \mathrm{~ns}$ & $-0.101 \mathrm{~ns}$ & $-2.522 * * *$ & $0.388 * * *$ \\
\hline SE & 3.891 & 0.001 & 0.099 & 0.224 & 0.022 \\
\hline SE & 36.823 & 0.003 & 0.274 & 1.206 & 0.100 \\
\hline \multicolumn{6}{|c|}{ Rio Branco (AIC 375.380) } \\
\hline Estimate & $47.646^{* * *}$ & $-0.002 * *$ & $-1.204 * * *$ & $0.472 * * *$ & $-0.185 * * *$ \\
\hline SE & 8.005 & 0.001 & 0.177 & 0.086 & 0.0417 \\
\hline \multicolumn{6}{|c|}{ Porto Nacional (AIC 102.820) } \\
\hline \multicolumn{6}{|c|}{ Sinop (AIC 167.480) } \\
\hline Estimate & $-70.738 * * *$ & $-0.047 * * *$ & $1.028 * * *$ & $1.343 * * *$ & $0.264 * * *$ \\
\hline SE & 8.706 & 0.005 & 0.214 & .0156 & 0.028 \\
\hline \multicolumn{6}{|c|}{ Luís Eduardo Magalhães (AIC 94.159) } \\
\hline Estimate & $-42.095 * * *$ & $0.004 * * *$ & $0.088 \mathrm{~ns}$ & $1.537 * * *$ & $0.097 * * *$ \\
\hline SE & 8.214 & 0.001 & 0.247 & 0.400 & 0.022 \\
\hline \multicolumn{6}{|c|}{ Planaltina (AIC 247.470) } \\
\hline Estimate & $12.475 * *$ & $0.002 \mathrm{~ns}$ & $-0.609 * * *$ & $0.106 \mathrm{~ns}$ & $0.060 * *$ \\
\hline SE & 4.686 & 0.001 & 0.158 & 0.173 & 0.0197 \\
\hline \multicolumn{6}{|c|}{ Uberaba (AIC 73.275) } \\
\hline Estimate & $-102.700 * *$ & $0.001 \mathrm{~ns}$ & $3.218^{* *}$ & $-2.711 * *$ & $0.767 * *$ \\
\hline \multicolumn{6}{|c|}{ Passo Fundo (20.082) } \\
\hline Estimate & $-18.697 \mathrm{~ns}$ & $0.032 \mathrm{~ns}$ & $-0.067 \mathrm{~ns}$ & $1.417 \mathrm{~ns}$ & $-0.139 \mathrm{~ns}$ \\
\hline SE & 48.558 & 0.038 & 2.287 & 3.657 & 0.697 \\
\hline \multicolumn{6}{|c|}{ Bagé (AIC 12.00) } \\
\hline Estimate & $-223.100 n s$ & $0.191 \mathrm{~ns}$ & $13.460 \mathrm{~ns}$ & $-15.570 \mathrm{~ns}$ & $0.942 \mathrm{~ns}$ \\
\hline SE & $2.182 \mathrm{e}+06$ & $6.739 \mathrm{e}+02$ & $6.244 \mathrm{e}+04$ & $5.915 \mathrm{e}+04$ & $2.018 \mathrm{e}+04$ \\
\hline
\end{tabular}

amounts of nutrients in their tissues and less physical or chemical defense structures (Tamiru et al. 2015).

The large number of specimens collected in five nights of a single month (531) in Alto Alegre - RR (Table 2) refers to the large population numbers of the species that, if under favorable environmental conditions and food availability, will determine the occurrence of outbreaks (Bodkin 1914, Watson 1933, Fennah 1947, Labrador 1964, Capriles \& Ferrer 1973, Costilla et al. 1973, Hseih 1979, Calderón et al. 1981, Silvain 1984, Silvain \& Dauthuille 1985, Gibbs 1990, Jiménez et al. 1997, Correia et al. 1999, Sánchez Soto \& Ortiz Garcia 1999, Minno \&
Snyder 2008) but mainly due to its relation with higher temperatures in tropical and equatorial areas, since the optimal development temperature is $30^{\circ} \mathrm{C}$ (Ferreira \& Parra 1985).

This relation between greater abundance and higher temperature is in line with the significance of the negative regression between latitude and abundance found in this study (Figure 2). Indeed, despite the wide range of occurrences in the American continent, the largest number of studies that emphasize the importance of $M$. latipes as a pest refers to areas located in lower latitudes or that have climates characterized by high temperatures, especially in Central American countries and the 
Caribbean (e.g. Bodkin 1914, Fennah 1947, Labrador 1964, Capriles \& Ferrer 1973, Hseih 1979, Calderón et al. 1981, 1982, Silvain 1984, Silvain \& Dauthuille 1985, Gibbs 1990, Jiménez et al. 1997, Teixeira \& Townsend 1997, Correia et al. 1999, Sánchez Soto \& Ortiz Garcia 1999, Minno \& Snyder 2008). Considering the specific area of this study the greatest importance of $M$. latipes as a pest is highlighted by several studies in hot and humid regions, especially the Amazon (Silva et al. 1994, Teixeira \& Townsend 1997, Fazolin et al. 2009), northeastern coast (Mendonça Filho 1972, Costa et al. 1983, Correia et al. 1999) and Southeast of Brazil (Hempel 1914, 1920a, 1920b, Fonseca 1944, Lopes 1955, 1961, Cavalcante 1977, Ferreira 1984, Cruz 1991).

Considering the higher latitudes sampled in this study (Table 2, Figure 1) it is important to note that even in places below the tropical line there are outbreaks with significant production losses, both in the Northern hemisphere (Vickery 1924, Watson 1933, Genung \& Allen Jr. 1974, Ogunwolu \& Habeck 1975, Reinert 1975, Koehler et al. 1977, Minno \& Snyder 2008), and in the southern hemisphere, in Argentina (Costilla et al. 1973, Salvatore \& Willink 2004, Acosta et al. 2005, Salvatore et al. 2009) and in Uruguay (Bentancourt \& Scatoni 1996). However, the greater occurrence of M. latipes and outbreaks are conditioned to the hottest times of the year. This is due to the fact that, even in high latitudes, in the subtropic, during summer solstice temperatures can be high, conditioning a favorable environment to increasing the development of population, which may cause outbreaks in specific years (Cavalcanti et al. 2009). On the other hand, it should be considered, in addition to the photoperiod, that winter temperatures are close to or below the base development temperature of $13.7^{\circ} \mathrm{C}$ (Ferreira \& Parra 1985). This determines that in addition to prolonging the life cycle, as reported in the Northern Hemisphere, to survive against adverse weather conditions, instars need to develop pupal diapause (to be confirmed in Brazil) or adults must migrate to regions where temperatures are higher, and return when local conditions become favorable to their development (ex. Ferguson et al. 1991, Brou Jr. 2004, Wagner et al. 2011).

The numbers presented in this study consist of a small sample represented by the moths caught in the range of the traps covers (estimated at 400m to Spodoptera frugiperda - Vilarinho et al. 2011) at just twelve points in Brazil. These samples represent only adults that survived the weather conditions and all natural enemies present during all stages and collection time. It is also not possible to associate adults with the host plants on which the caterpillars fed and developed. Despite all these limitations, the high number of adults of $M$. latipes collected in all locations (Figure 1, Table 2) highlights its importance as a key specimes in grass-insect interactions in most of Brazil (e.g. Costa 1944a, 1944b, Fonseca 1944, Pugliese 1954, Lopes 1955, 1961, Queiroz 1965, Mendonça Filho 1972, Cavalcante 1977, Planalsucar 1982, Costa et al. 1983, Ferreira 1984, Ferreira \& Parra 1985, Cruz 1991, Silva et al. 1994, Teixeira \& Townsend 1997, Correia et al. 1999, Fazolin et al. 2009), as well as in most countries of the American continent (e.g. Dine 1913, Bodkin 1914, Holloway 1933, Watson 1933, Fennah 1947, Dinther 1960, Guagliumi 1962, Labrador 1964, Capriles \& Ferrer 1973, Costilla et al. 1973, Genung \& Allen Jr. 1974, Ogunwolu \& Habek 1975, Koehler et al. 1977, Mahadeo 1977, Hseih 1979, Calderón et al. 1981, 1982, Silvain 1984, Silvain \& Dauthuille 1985, Miret 1986, Jiménez et al. 1997, Milán et al. 1990, Portillo et al. 1991, Saunders et al. 1998, Piedra \& Carrilo 1999, Páliz-Sánchez \& Mendoza-Mora 1999, Sánchez
Soto \& Ortiz García 1999, Pitre et al. 1999, Vergara et al. 2001, Brou Jr. 2004, Salvatore \& Willink 2004, Acosta et al. 2005, Marquez 2013). Regarding the fact that it is one of the most predominant specimes, it is important to consider its role in natural ecosystems, especially in agroecosystems where there is a greater proportion or intensification of grass planting, including grains, forages, pastures and sugar cane (e.g. Labrador 1964, Koehler et al. 1977, Calderón et al. 1981, 1982, Costa et al. 1983, Cruz \& Santos 1983, Ferreira 1984, Silvain 1984, Silvain \& Dauthuille 1985, Miret 1986, Silva \& Carvalho 1986, Gibbs 1990, Milán et al. 1990, Cruz 1991, Jiménez et al. 1997, Teixeira \& Townsend 1997, Páliz-Sánchez \& Mendonza-Mora 1999, Pitre et al. 1999, Vergara et al. 2001, Acosta et al. 2005, Salvatore et al. 2009, Marquez 2013, Hickel et al. 2018). Among the roles to be considered for this species, it is also considered a primary consumer, nutrient cycling promoter, food source for pests (including insects, birds and mammals), parasitoids and pathogens (Wagner et al. 2011).

In relation to the natural enemy organisms of $M$. latipes, there are studies about the relationship of a countless number of species associated with their natural biological control (predators, parasitoids and pathogens), in different stages of development, in different countries of the American Continent (e.g. Sauer 1946, Silva et al. 1968, Lopes 1969, Gonçalves \& Gonçalves 1974a, 1974b, Genung et al. 1976, Guimarães 1977, De Santis 1979, 1989, Lourenção et al. 1982, Collins \& Watson 1983, King \& Saunders 1984, Hall 1985, Santos 1989 , Rogers et al. 1990a, 1990b, Galán \& Rodríguez 1991, Cave 1992, Rogers \& Marti Jr. 1993, Whitaker Jr. et al. 2007, Rolfe et al. 2014). These studies mention that the action of several natural enemies is important when analyzing the abundance data of $M$. latipes in any area of its distribution. As shown for other owlet moths (Pereira et al. 2018), their population levels are maintained, at least most of the time, by the action of natural enemies. This might be related to the different population levels, between locations and in different months presented in this study (Table 2).

In relation to ecological balance promoted by the association and the presence of natural enemies, it is important to note that throughout the American continent $M$. latipes occurs in conjunction with other owlet moths associated with grasses, including congeneric species (Babayan et al. 1975, Ogunwolu \& Habek 1975, Koehler et al. 1977, Brou Jr. 2004) and, specially, S. frugiperda (J.E. Smith) (e.g. Fonseca 1944, Pugliese 1954, Lopes 1955, 1961, Guagliumi 1962, Queiroz 1965, Mahadeo 1977, Hseih 1979, Calderón et al. 1981, Costa et al. 1983, Silvain 1984, Silvain \& Dauthuille 1985, Portillo et al. 1991, Páliz-Sánchez \& Mendoza-Mora 1999, Pitre et al. 1999, Sánchez Soto \& Ortiz Garcia 1999, Fazolin et al. 2009 ) forming species complexes. Spodoptera frugiperda is a polyphagous species (Montezano et al. 2018) with high biotic potential (Montezano et al. 2019a, 2019b) and, as in this study (Table 2, fig. 1) it was collected in all the locations presented here (Piovesan et al. 2018). It is important that M. latipes and other owlet moths, including $S$. frugiperda share the same predators, pathogens, also egg, larvae and pupae parasitoids (Silva et al. 1968, Rogers \& Marti Jr. 1993, Camera et al. 2010). This determines that the presence of $M$. latipes, even in low populations, allows the maintenance of populations of different groups of natural enemies in natural ecosystems and agroecosystems. Thus, the occurrence of immature M. latipes allows the maintenance of a wide range of natural enemies, it is essential for 
the maintenance of natural biological control over time, for the entire species complex.

The significant relationship between the abundance of $M$. latipes with at least one of the meteorological variables (Table 3), in practically all Brazilian territory except in the three most southern locations (Figure 1) reinforces the strong association between population variations and climatic conditions mentioned in several studies (e.g. Bertels 1970, Genung \& Allen Jr. 1974, Babayan et al. 1975, Calderón et al. 1981, Gibbs 1990, Jiménez et al. 1997, Pitre et al. 1999, Salvatore \& Willink 2004, Fazolin et al. 2009, Hickel et al. 2018). The relationship between population variations and climatic conditions, is evidenced by the large number of moths collected in rainy months (July, August and September), in Alto Alegre, RR, located in the Northern Hemisphere (Table 2) while all the other places are located in the Southern Hemisphere, these same months correspond to winter time (dry or cold), with very low population levels. Indeed, studies always relate the highest population levels with warm months, preferably during the rainy season in the Northern Hemisphere (Bodkin 1914, Vickery 1924, Watson 1933, Fennah 1947, Capriles \& Ferrer 1973, Calderón et al. 1981, Gibbs 1990, Minno \& Snyder 2008) as in the Southern Hemisphere (Lopes 1955, Costilla et al. 1973, Carvalho 1976, Lourenção et al. 1982, Teixeira \& Townsend 1997, Correia et al. 1999, Salvatore \& Willink 2004, Acosta et al. 2005).

Regarding the different numbers of moths collected each month, in each location (Table 2) besides the climatic characteristics (Cavalcanti et al. 2009), biogeographic and phytophysiognomic variations should also be considered (Heppner 1991). Although M. latipes is an oligophytophagous species with a preference for grasses (ex. Ogunwolu \& Habeck 1975, Wagner et al. 2011), in each location the moths were able to choose to lay eggs on plants arranged as a space-time mosaic containing different native and/or cultivated species that served as food for their larvae.

The $M$. latipes abundance spatial variations described in this study, combined with the knowledge of its great dispersion capacity, including migration (ex. Barth 1958, Ferguson et al. 1991, Wagner et al. 2011, Alves et al. 2019) point to the need for studies related to the molecular characterization of populations in order to allow assessments of local populations, migration routes and/or gene flow as done for other owlet moths (e.g. Palma et al. 2015, Nagoshi et al. 2017). This information is extremely important to assess whether the occurrence of population outbreaks of this species is related only to the fast reproduction of local populations or whether it involves dispersion or migration events. Thus, it should be noted that even in Southmost areas, where the abundance of M. latipes was extremely low, there are several registers of its occurrence (ex. Tarragó et al. 1975, Link 1977, Specht \& Corseuil 2002, Specht et al. 2004, 2005, Zenker et al. 2010) indicating that the species was present in more than 50\% of weekly collections between July 1994 and June 1995 (Specht \& Corseuil, 2002). Furthermore, further to the South, Bentancourt \& Scatoni (2006) relate sporadic population outbreaks of this species in Uruguay, noting that, even at greater latitudes, the occurence of this species is relatively constant with increases in population linked to favorable conditions to its development. Especially in these places it is questioned whether the presence of the species is due to a local population or as a result of migration as described for the Northern Hemisphere (Brou Jr. 2004, Wagner et al. 2011).
The results of this study as well as most previous publications (ex. Carvalho 1976, Lourenção et al. 1982, Fazolin et al. 2009, Bentancourt \& Scatoni 1996, Saunders et al. 1998, Wagner et al. 2011) indicates that $M$. latipes, besides having a wide distribution, it has low population levels during most of the year, with sporadic population outbreaks during favorable weather conditions, food availability and inadequate cultural management. Therefore, it must be considered that agricultural occupation has modified most of the ecosystems where the effect of seasonal variations on native host plants is minimized by cultivating grasses that serve as alternative hosts more resistant to drought in the savanna and to the cold in greater latitudes. These plants can serve as a green bridge between the most favorable seasons to the development of M. latipes and other insects (Favetti et al. 2017). Considering grasses as host plants, it must be taken into consideration that $M$. latipes has food available both in open native environments and in the most diverse combinations of forage, grain and sugar production. In addition to these plants directly related to production, other crops should be considered for soil protection and biomass production to be incorporated in crop rotation systems (Dias et al. 2016, Favetti et al. 2017), integrated crop-livestock systems (Vilela et al. 2011) and even when introduced grasses become pests occupying most ecosystems for most of the year (Minno \& Snyder 2008).

Even though this study shows an inverse relationship between latitude and $M$. latipes abundance along with other meteorological variables, it should be considered that abiotic factors are conditional to species development, and not necessarily associated with the decrease of abundance. Therefore, additional hypotheses need to be tested considering specific abundance and environmental factors. One example is the high abundance of $M$. latipes in tropical areas, it can be related to favorable conditions, while that in subtropical regions only summer months present favorable conditions. On the other hand, areas presenting favorable conditions all year long also provide a high number of natural enemies. Thus, due to the large number of variables related to M. latipes itself (which includes developmental biology in different conditions, the ability to diapause, migrate, defend against natural enemies) and biotic factors associated with each location (availability of different host plants native or cultivated, presence and abundance of natural enemies, interspecific competition) cause the associations established between population levels, latitude and environmental factors to be explored continuously. A better understanding of these associations will allow a more accurate understanding of the effects of local environmental variations and global climate changes on insect populations, pests or not.

\section{Acknowledgments}

To FAP-DF for the Master's scholarship of the first author, to CNPq (403376/2013-0 and 306601/2016-8) and Embrapa (SEG n ${ }^{\circ}$ 02.13.14.006.00.00 and 10.18.03.027.00.00). To ICMBio, MMA for authorizing the Scientific Activities SISBIO no 48218-3). To people involved in collections: Adriano Q. Mesquita, Américo I. Ciociola Júnior, André L. Filipiake, Antônio Carlos S. Araújo, Balbino A. Evangelista, Brenda M. Moreira, Daniel B. Fragoso, Daniel R. SosaGómez, Denivaldo C. Castro, Dirceu Pratissoli, Erivaldo A. Santos, Felipe O. Mateus, Harry Ebert, João B.G. Santos Filho, Jorge U.P. Corrêa, José A. Teston, José R. Carvalho, José S. Zanúncio Júnior, 
Leonardo Mardgan, Maicon Coradini, Marco A.P. Silva, Marcos R.O. Serpa, Murilo Fazolin, Naylor B. Perez, Oriverto Tonon, Paulo R.V.S. Pereira, Rafael M. Pitta, Rodison N. Sisti, Sandra M.M. Rodrigues, Tiago C.C. Lima and Wilson Pozenato. We also would like to thank the three annonimous reviwers who contributed to the improvement of this manuscript.

\section{Authors Contributions}

Vander C. M. Claudino: Substantial contribution in the concept and design of the study; contribution to data collection; data analysis and interpretation; manuscript preparation and critical revision, adding intelectual content. Alexandre Specht: Substantial contribution in the concept and design of the study; contribution to data collection; data analysis and interpretation; manuscript preparation and critical revision, adding intelectual content.

Elisângela G. Fidelis: Contribution to data collection; data analysis and interpretation; manuscript preparation and critical revision.

Vânia F. Roque-Specht: Contribution to data collection; data analysis and interpretation; manuscript preparation and critical revision.

Débora G. Montezano: Contribution to data analysis and interpretation; manuscript preparation and critical revision, adding intelectual content.

Pedro R. Martins: Contribution to data analysis and interpretation; manuscript preparation and critical revision; Fernando A.M. Silva: Contribution to data collection; data analysis and interpretation; manuscript preparation and critical revision.

Juaci V. Malaquias: Substantial contribution in the concept and design of the study; contribution to data analysis and interpretation; manuscript preparation and critical revision.

\section{Conflict of Interest}

The authors declare that they have no conflict of interest related to the publication of this manuscript.

\section{References}

ACOSTA, M., WILLINK, E., SAAVEDRA, J. \& SALVATORE, A.R. 2005. Pérdidas en el rendimiento cultural y fabril causadas por el gusano cuarteador, Mocis latipes (Guen) en caña de azúcar. Av. Agroind., 26: 12-14.

ALARCÓN, L., CORTIÑAS, J., JIMÉNEZ, S.F., LAGUNA, D., CASTRO, J.A., CARBONELL, M. \& RODRÍGUEZ, M. 2004. Zonificación de Mocis latipes (Guenée) (Lepidoptera: Noctuidae) en las empresas pecuarias de la Provincia de Las Tunas, Cuba. Fitosanidad, 8: 17-20.

ALVAREZ-R., A. \& SANCHEZ-G., G. 1981. Ciclo de vida y descripcion del gusano agrimensor, Mocis latipes. Rev. ICA, 16: 57-63.

ALVES, R.J.V., COSTA, L.A.A., SOARES, A., SILVA, N.G. \& PINTO, Â.P. 2019. Open ocean nocturnal insect migration in the Brazilian South Atlantic with comments on flight endurance. PeerJ, 7: e7583.

ANGULO, A.O. \& JANA-SÁENZ, C. 1983. Catalogo crítico, ilustrado y claves de Catocalinae y Ophiderinae para Chile (Lepidoptera: Noctuidae). Gayana Zool. 45: 3-26.

BABAYAN, L., CABRERA, R.A. \& AZCUY, A.F. 1975. Algunos datos sobre ei género Mocis (Lepidoptera, Noctuidae) como plaga de la caña de azúcar em Cuba. Rev. Agric. (La Habana), 8: 36-46.

BARTH, R. 1958. Observações biológicas e meteorológicas feitas na Ilha de Trindade. Mem. Inst. Oswaldo Cruz 56(1): 261-279.
BECK, H., ZIMMERMANN, N., MCVICAR, T., VERGOPOLAN1, N., BERG, A. \& WOOD, E.F. 2018. Present and future Köppen-Geiger climate classification maps at 1-km resolution. Sci Data 5: 180214.

BENTANCOURT, C.M. \& SCATONI, I.B. 2006. Lepidópteros de importancia económica en el Uruguay: Reconocimiento, biologia y daños de las plagas agrícolas y forestales. Editorial Hemisferio Sur, Montevideo.

BERNARDI, O., GARCIA, M.S., SILVA, E.J.E., ZAZYCHI, L.C.F., BERNARDI, D. \& FINKENAUER, E. 2011. Levantamento populacional e análise faunística de Lepidoptera em Eucalyptus spp. no município de Pinheiro Machado, RS. Ci. Fl., 21(4): 735-744.

BERTELS, A. 1970. Estudo da influência da umidade sobre a dinâmica de populações de lepidópteros, pragas do milho. Pesq. Agropec. Bras., 5(1): $67-79$.

BERTELS, A.M. 1975. Insetos-pragas da soja e seu combate. Embrapa - Bol. Técnico, 100: 1-33.

BERTELS, A.M. \& ROCHA, A.B. 1950. Observações preliminares sobre pragas do milho. Agros, 3: 160-183.

BETHUNE, C.J.S. 1869. Notes on Canadian Lepidoptera, part III. Can. Entomol., 1: $85-89$.

BIEZANKO, C.M., RUFFINELLI, A. \& CARBONELL, C.S. 1957. Lepidoptera del Uruguay, lista anotada de especies. Rev. Fac. Agron., 46: 3-152.

BIEZANKO, C.M., RUFFINELLI, A. \& LINK, D. 1974. Plantas y otras sustancias alimenticias de las orugas de los lepidópteros uruguayos. Rev. Centro de Ciências Rurais, 4(2): 107-148.

BISSELL, T.L. 1940. Insects damaging forage crops. Ga. Exp. Sta. - Ann. Rep., 52: 63.

BODKIN, G.E. 1914. The grass moth (Remigia repanda), a pest of sugar cane, rice, and paragrass in British Guiana. J. Bd. Agric. Brit. Guiana, 7: 171-177.

BROU Jr., V.A. 2004. The Noctuidae genus Mocis Hübner in Louisiana. Southern Lepidopterists' News, 26: 35-37.

CALDERÓN, M., VARELA, F. \& QUINTERO, E. 1981. Falso medidor de los pastos Mocis latipes Guenée (Lepidoptera: Noctuidae), plaga esporádica em Carimagua. Pastos Tropicales - Boletín CIAT, 4: 8-12.

CALDERÓN, M., VARELA, F.A. \& VALENCIA-G, C.A. 1982. Descripción de las plagas que atacan los pastos tropicales y características de sus daños. CIAT, Cali.

CAMERA, C., DEQUECH, S.T.B., RIBEIRO, L.P. \& QUERINO, R.B. 2010 Primeiro relato de Trichogramma rojasi parasitando ovos de Spodoptera frugiperda. Ciênc. Rural, 40(8): 1828-1830.

CAPINERA, J.L. 2005. Symposium - Relationships between insect pests and weeds: an evolutionary perspective. Weed Sci., 53(6): 892-901.

CAPRILES, J.M. \& FERRER, M.A.C. 1973. Severe attack on sugarcane and grasses by Mocis latipes (Guenée), (Lepidoptera: Noctuidae) in southwest Puerto Rico. J. Agr. U. Puerto Rico, 57(4): 348-349.

CARVALHO, R. 1976. Lagarta dos capinzais (Mocis latipes, Guenée 1852) no Espírito Santo: primeira abordagem do problema. EMCAPA, Vitória.

CAVALCANTE, R.D. 1977. Combate ao curuquere dos capinzais [Mocis latipes]. Bol. Fitossanitário - Bayer do Brasil S.A., 238: 1-3.

CAVALCANTI, I.F.A., FERREIRA, N.J., SILVA, M.G.A.J. \& DIAS, M.A.F.S. 2009. Tempo e clima no Brasil. Editora Oficina de Textos, São Paulo.

CAVE, R.D. 1992. Inventory of parasitic organisms of the striped grass looper, (Lepidoptera: Noctuidae), in Honduras. Fla. Entomol., 75(4): 592-598.

COLLINS, C.T. \& WATSON, A. 1983. Field observations of bird predation on Neotropical moths. Biotropica, 15(1): 53-60.

CORREIA, J.S., FERRAZ, M.C.V.D. \& SANTOS, Z.F.A.F. 1999. A lagarta-doscapinzais, Mocis latipes (Guenée, 1852), importante praga das pastagens no estado da Bahia. EBDA - Circular Técnica, 8: 1-21.

COSTA, J.M., CORREIA, J.S., SANTOS, Z.F.D'A.F. \& FERRAZ, M.C.V.D. 1983. Pragas das pastagens no Estado da Bahia e meios de controle. EPABA, Salvador.

COSTA, R.G. 1944a. Pragas das plantas cultivadas do Rio Grande do Sul. Secretaria de Estado dos Negócios da Agricultura, Indústria e Comércio, Porto Alegre. 
COSTA, R.G. 1944b. Principais pragas do trigo. Bol. Agron. 8(1): 7-9.

COSTILLA, M.A., BASCO, H.J., LEVI, C.A. \& OSORES, V.M. 1973. La oruga cuarteadora Mocis latipes (Guen) y su importancia como plaga de la caña de azúcar: biología, daño y control. Bol. Estac. Exp. Agríc. Tucumán 112: 1-7.

CRUZ, I. 1991. Quantificação dos danos provocados pela lagarta militar Mocis latipes, em milho. Embrapa-CNPMS, Sete Lagoas, [Relatório Técnico Anual 1985-1987].

CRUZ, I. \& SANTOS, J.P. 1983. Estudo comparativo de biologia de Mocis latipes em dieta artificial e folhas de milho e sorgo. Pesq. Agropec. Bras., 18(2): 85-90.

DE SANTIS, L. 1979. Catálogo de los Himenópteros Calcidoideos de América al Sur de Los Estados Unidos. Comisión de Investigaciones Científicas, La Plata.

DE SANTIS, L. 1989 Catálogo de los Himenopteros Calcidoideos (Hymenoptera) al sur de los Estados Unidos. Segundo suplemento. Acta Entomol. Chilena, 15: 9-90.

DIAS, A.S., MARUCCI, R.C., MENDES, S.M., MOREIRA, S.G., ARAÚJO, O.G., SANTOS, C.A. \& BARBOSA, T.A. 2016. Bioecology of Spodoptera frugiperda (Smith, 1757) in different cover crops. Biosci. J., 32(2): 337-345.

DINE, D.L. 1913. The insects affecting sugarcane in Porto Rico. J. Econ. Entomol., 6(2): 251-257.

DINTHER, J.B.M. 1955. Laphygma frugiperda S. \& A. and Mocis repanda in Suriname. Entomolog. Ber., 15, 407-411; 427-431.

DINTHER, J.B.M. 1960. Insect pests of cultivated plants in Surinam. Bull. Agric. Exp. Stn. Suriname, 76: 1-159.

DIXON, A.P., FABER-LANGENDOEN, D., JOSSE, C., MORRISON, J. \& LOUCKS, C.J. 2014. Distribution mapping of world grassland types. J. Biogeogr., 41: 2003-2019.

FALANGHE, O. \& DIAS NETTO, N. 1961. Controle de lagartas dos trigais. Rev. Agricult., 36: 14-17.

FAVETTI, B.M., BRAGA-SANTOS, T.L., MASSAROLLI, A., SPECHT, A. \& BUTNARIU, A.R. 2017. Pearl millet: A green bridge for lepidopteran pests. J. Agric. Sci., 9(6): 92-97.

FAZOLIN, M., COSTA, C.R., ESTRELA, J.L.V., HESSEL, C.E. \& ANDRADE, C.M.S. 2009. Levantamento de insetos-praga associados aos capins TannerGrass, Tangola e Estrela-Africana no Acre. Amazônia: Ci. \& Desenv., 4(8): 161-173.

FENNAH, R.G. 1947. Mocis repanda, the Guinea-grass moth. The Insect Pests of Food Crops in the Lesser Antilles. (Ed. FENNAH R.G.), pp. 85-86. Dep. Agr. Windward and Leeward Islands, Grenada and Antigua.

FERGUSON, D.C., HILBURN, D.J. \& WRIGHT, B. 1991. The Lepidoptera of Bermuda: Their food plants, biogeography, and means of dispersal. Mem. Entomol. Soc. Can., 123: 1-105.

FERREIRA, M.J.M. \& PARRA, J.R.P. 1985. Biologia de Mocis latipes (Guenée, 1852) (Lepidoptera: Noctuidae) em diferentes temperaturas, para determinação das exigências térmicas. An. Soc. Entomol. Bras., 14(1): 75-88.

FERREIRA, S. 1984. Milho: como combater as pragas da cultura. Corr. Agríc., 1984: 625-627.

FONSECA, J.P. 1944. Lagartas dos milharais e outras culturas. Revta. Soc. Rural Bras., 4: 41-42.

FONSECA, J.P. \& AUTUORI, M. 1932. Principaes pragas do café no estado de São Paulo. Instituto Biológico de Defesa Agrícola e Animal, Divisão Vegetal, Seção de Entomologia e Parasitologia Agrícolas, São Paulo.

FORMENTINI, A.C., SOSA-GÓMEZ, D.R., PAULA-MORAES, S.V., BARROS, N.M. \& SPECHT, A. 2015. Lepidoptera (Insecta) associated with soybean in Argentina, Brazil, Chile and Uruguay. Ciênc. Rural, 45(12): 2113-2120.

FROST, S.W. 1957. The Pennsylvania insect light trap. J. Econ. Entomol., 50(3): 287-292.
GALÁN, M. \& RODRÍGUEZ, J. 1991. Registro de Trichogramma rojasi Nagaraja y Nagarkatti (Hymenoptera: Trichogrammatidae) para Cuba. Revta. Biol., 5: 177-181.

GENUNG, W.G. \& ALLEN Jr., R.J. 1974. Bionomics and control of the striped grass looper Mocis latipes in the Everglades and adjacent areas (Lepidoptera: Noctuidae). Belle Glade Agricultural and Research and Education Center, Belle Glade [Research Report EV-1974].

GENUNG, W.G., JANES, M.J. AND GREEN JR., V.E. 1976. Insects and other dietary items of Maynard's red-wing blackbird in relation to agriculture. Fla. Entomol., 59(3): 309-316.

GIBBS, I.H. 1990. The guinea grass moth- an occasional pest of pasture grasses in Barbados. Proceedings - Barbados Society of Technologists in Agriculture. Eighth Annual Conference 67-69.

GONÇALVES, C.R. \& GONÇALVES, A.J.L. 1974a. Novas observações sobre moscas da família Tachinidae parasitando lepidópteros. Ciên. Cult., 26(7-supl.): 337.

GONÇALVES, C.R. \& GONÇALVES, A.J.L. 1974b. Novas observações sobre moscas da família Tachinidae que parasitam lepidópteros. Rev. Bras. Biol., 34(4): 531-534.

GUAGLIUMI, P. 1962. Las plagas de la caña de azúcar en Venezuela. Centro de Investigaciones Agronomicas, Maracay.

GUAGLIUMI, P. 1973. Pragas da cana-de-açúcar: nordeste do Brasil. Instituto do Açúcar e do Álcool, Rio de Janeiro.

GUIMARÃES, J.H. 1977. Host-parasite and parasite-host catalogue of South American Tachinidae (Diptera). Arq. Zool., 28: 1-131.

HALL, D.G. 1985. Parasitoids of grasslooper prepupae and pupae in South Florida sugarcane. Fla. Entomol., 68(3): 486-487.

HAYWARD, K.J. 1960. Insectos Tucumanos Perjudiciales. Rev. Ind. Agríc. Tucumán, 42: 1-101

HEMPEL, A. 1914. A lagarta do milharal. Bol. Agric., 15(2): 168-170.

HEMPEL, A. 1920a. As pragas e moléstias do arroz no Estado de São Paulo. Rev. Mus. Paul., 12(2): 145-150.

HEMPEL, A. 1920b. As pragas importantes do milho no Estado de São Paulo. Rev. Mus. Paul., 12(2): 379-387.

HEPPNER, J.B. 1991. Faunal regional and the diversity of Lepidoptera. Trop. Lep., 2(suppl. 1): 1-85.

HICKEL, E.R., PRANDO, H.F. \& EBERHARDT, D.S. 2018. Lagartas nas lavouras catarinenses de arroz irrigado: ocorrência, monitoramento e manejo integrado. Bol. Técn. Epagri, 182: 1-48.

HOLLOWAY, T.E. 1933 Insect pests of sugarcane. Facts about sugar, 28: 216-219.

HSEIH, C.Y. 1979. Major insect pests of irrigated rice in the lower Amazon Basin. IRRN, 4: 16.

JIMÉNEZ, S., CORTIÑAS, J., SUÁREZ, M., ALMAGUEL, L. \& GÓMEZ, G. 1997. Regionalización de Mocis latipes (Guénée) (Lepidoptera: Noctuidae) en las zonas productoras de pastos de la provincia de La Habana. Agrotecnia de Cuba, 27: 80-85.

KELLOGG, E.A. 2001. Evolutionary history of the grasses. Plant Physiol. 125: 1198-1205.

KIMBALL, C.P. 1965. Arthropods of Florida and neighboring land areas. Lepidoptera of Florida. Florida Department of Agriculture, Division of Plant Industry, 1: 1-125.

KING, A.B.S. \& SAUNDERS, J.L. 1984. Las plagas invertebradas de cultivos anuales alimenticios en América Central. $2^{\text {nd }}$ ed. CATIE, Turrialba

KLEYLA, P.C., MINNICK, D.R. \& RUELKE, O.C. 1979. Alfalfa plant resistance to insects in Florida. Soil \& Crop Sci. Soc. Fla. Proc., 38: 16-17.

KOEHLER, P.G., GOUGER, R.J. \& SHORT, D.E. 1977. Control of striped grass loopers and armyworms in pasture: 1976. Fla. Entomol., 60(2): 102-104.

KRAUEL, J.J., BROWN, V.A., WESTBROOK, J.K. \& MCCRACKEN, G.F. 2018. Predator-prey interaction reveals local effects of high altitude insect migration. Oecologia, 186(1): 49-58. 
LABRADOR, S.J.R. 1964. Estudios de biologia y combate del gusano medidor de los pastes Mocis repanda F. en el estado Zulia. Univ. Zulia. Rev. Univ. Zulia, 8: 111-144.

LINK, D. 1977. Abundância relativa de alguns Noctuidae, em armadilha luminosa, em Santa Maria, RS. Rev. Centro de Ciências Rurais, 7(4): 331-351.

LOPES, N.F.C. 1955. Lagartas das pastagens, Mocis repanda (Fabr. 1794) e Laphygma frugiperda (Smith \& Abbott, 1797). Agric. Pec., 27: 20-21.

LOPES, N.F.C. 1961. Combate as lagartas das pastagens. Seleções Agrícolas, 10: $43-45$

LOPES, H.S. 1969. 103 - Family Sarcophagidae. A catalogue of the Diptera of the Americas South of the United States. (ed. PAPAVERO, N.), Departamento de Zoologia, Secretaria de Agricultura, São Paulo. pp. 01-88

LOURENÇÃO, A.L., BERTI FILHO, E. \& FERRAZ, C.V.D. 1982. Inimigos naturais de Mocis latipes (Guenée, 1852). Bragantia, 41(1): 237-240.

MAHADEO, C.R. 1977. Trinidad - Mocis latipes and Spodoptera frugiperda on sugarcane. FAO Plant Prot. Bull., 25(4): 211-212.

MARQUEZ, M.J. 2013. Defoliadores en caña de azúcar: falso medidor. Boletin Cañamip 11: 1-4

MENDONÇA FILHO, A.F. 1972. Insetos observados nos canaviais do Estado de Alagoas - Brasil, durante o ano de 1971. An. Soc. Entomol. Bras., 1: 25-41.

MILÁN, O., LUJÁN, M. \& MATOS, N. 1990. Determinación de los estadios larvales de Mocis latipes como plaga de los pastos. Ciencia y Técnica en la Agricultura - Protección de plantas, 13: 71-78.

MINNO, M.C. \& SNYDER, K. 2008. Defoliation of the invasive weed paragrass (Urochloa mutica) (Poaceae: Panicoideae) by Mocis latipes (Noctuidae: Catocalinae) in East - Central, Florida. Southern Lepidopterist's News, 30(4): $145-146$

MIRET, R. 1986. Grado de preferencia de Mocis latipes (Guenée) en cultivares de Bermuda y pasto estrela. Pastos y Forrajes, 9: 37-42.

MONTEZANO, D.G., SPECHT, A., SOSA-GOMEZ, D.R., ROQUE-SPECHT, V.F., SOUSA-SILVA, J.C., PAULA-MORAES, S.V., PETERSON, J.A. \& HUNT, T.E. 2018. Host plants of Spodoptera frugiperda (Lepidoptera: Noctuidae) in the Americas. Afr. Entomol., 26(2): 286-300.

MONTEZANO, D.G., SPECHT, A., SOSA-GÓMEZ, D.R., ROQUE-SPECHT, V.F., PAULA-MORAES, S.V., PETERSON, J.A. \& HUNT, T.E. 2019a. Developmental parameters of Spodoptera frugiperda (Lepidoptera: Noctuidae) immature stages under controlled and standardized conditions. J. Agric. Sci., 11(8): 76-89.

MONTEZANO, D.G., SPECHT, A., SOSA-GÓMEZ, D.R., ROQUE-SPECHT, V.F., MALAQUIAS, J.V., PAULA-MORAES, S.V., PETERSON, J.A. \& HUNT, T.E. 2019b. Biotic potential and reproductive parameters of Spodoptera frugiperda (J.E. Smith, 1797) (Lepidoptera: Noctuidae). J. Agric. Sci., 11(13): 240-252.

NAGOSHI, R.N., FLEISCHER, S., MEAGHER, R.L., HAY-ROE, M., KHAN, A., MURÚA, M.G., SILVIE, P., VERGARA, C. \& WESTBROOK, J. 2017. Fall Armyworm migration across the Lesser Antilles and the potential for genetic exchanges between North and South American populations. PLoS One 12(2): e0171743.

OGUNWOLU, E.G. \& HABECK, D.H. 1975. Comparative life histories of three Mocis spp. in Florida (Lepidoptera: Noctuidae). Fla. Entomol., 58(2): 97-103.

PÁLIZ-SÁNCHEZ, V. \& MENDOZA-MORA, J. 1999. Plagas del maíz (Zea mays). En el litoral ecuatoriano, sus características y su control. INIAP, Quito

PALMA, J., MAEBE, K., GUEDES, J.V.C. \& SMAGGHE, G. 2015. Molecular variability and genetic structure of Chrysodeixis includens (Lepidoptera: Noctuidae), an important soybean defoliator in Brazil. PLoS One, 10(3): e0121260

PASTRANA, J.A. 2004. Los Lepidópteros Argentinos: sus plantas hospedadoras y otros substratos alimenticios. Sociedad Entomológica Argentina, Buenos Aires.

PEDIGO, L.P. \& RICE, M.E. 2009. Entomology and pest management. Prentice Hall, New Jersey.
PEREIRA, R.R., NEVES, D.V.C., CAMPOS, J.N., SANTANA JR., P.A., HUNT, T.E. \& PICANCCO, M.C. 2018. Natural biological control of Chrysodeixis includens. Bull. Entomol. Res., 108(6): 831-842.

PIEDRA, F. \& CARRILLO, E.L. 1999. Biología y consumo de alimento de Mocis latipes Guenée en diferentes temperaturas con pasto estrella (Cynodon niemfuensis). Fitossanidad, 3: 11-15.

PIGATTI, A. \& MELLO, E.J.R. 1960. Sensibilidade da lagarta dos capinzais Mocis repanda (F.) aos inseticidas modernos. Arq. Inst. Biol., 27: 31-34.

PIOVESAN, M., CARNEIRO, E., SPECHT, A. \& CASAGRANDE, M.M. 2018. Where and when? How phenological patterns of armyworm moths (Lepidoptera: Noctuidae) change along a latidudinal gradient in Brazil. Bull. Entomol. Res., 109(4): 490-499.

PITRE, H.N., PORTILLO, H.E., MECKENSTOCK, D., CASTRO, M., TRABANINO, R. \& CAVE, R. 1999. La langosta del sorgo y el maíz. Zamorano: Escuela Agrícola Panamericana, Zamorano.

PLANALSUCAR. 1982. Guia das principais pragas da cana de açúcar no Brasil. Planalsucar, Brasil.

PORTILLO, H.E., PITRE, H.N., MECKENSTOCK, D.H. \& ANDREWS, K.L. 1991. Langosta: A lepidopterous pest complex on sorghum and maize in Honduras. The Florida Entomologist, 74, 287-296.

PUGLIESE, A. 1954. As lagartas da folha do arroz. Lav. Arroz., 8: 15-16.

QUEIROZ, G.F. 1965. Lagartas das folhas da cana-de-açúcar. Bras. Açucar., 65: 81.

R DEVELOPMENT CORE TEAM. 2017. R: A language and environment for statistical computing. R Foundation for Statistical Computing, Vienna. www.r-project.org (last access at 09/Dec/2017).

REINERT, J.A. 1975. Life history of the striped grassworm, Mocis latipes (Guenee). An. Entomol. Soc. Am., 68(2): 201-204.

REINIGER, C.H. 1946. Dominada uma lagarta que atacava os canaviais de Campos. Bol. Minist. Agric., 34: 125.

ROGERS, C.E. \& MARTI Jr., O.G. 1993. Infestation dynamics and distribution of Noctuidonema guyanense (Nematoda: Aphelenchoididae) on adults of Spodoptera frugiperda and Mocis latipes (Lepidoptera: Noctuidae). Fla. Entomol., 76(2): 326-333.

ROGERS, C.E., MARTI, O.G., SIMMONS, A.M. \& SILVAIN, J.F. 1990a. Host range of Noctuidonema guyanense (Nematoda: Aphelenchoididae): An ectoparasite of moths in French Guiana. Environm. Entomol., 19(3): 795-798.

ROGERS, C.E., SIMMONS, A.M. \& MARTI, O.G. 1990b. Parasitism of Lepidoptera adults by Noctuidonema guyanense Remillet and Silvain (Nematoda: Aphelenchoididae) in southeastern United States. J. Agric. Entomol., 7(3): 241-245.

ROLFE, A.K., KURTA, A. \& CLEMANS, D.L. 2014. Species-level analysis of diets of two mormoopid bats from Puerto Rico. J. Mammal., 95(3): 587-596.

SALVATORE, A.R., LÓPEZ, G. \& WILLINK, E. 2009. Capítulo 11 - Plagas em el cultivo de caña de azúcar. Manual del Cañero (ROMERO, E.R., DIGONZELLI, P.A. AND SCANDALIARIS, J. Eds.), pp.143-150. Estación Experimental Agroindustrial Obispo Columbres, Las Talitas.

SALVATORE, A.R. \& WILLINK, E. 2004. La oruga cuarteadora, Mocis latipes (Guen.) en caña de azúcar. Av. Agroind., 25: 14-16.

SÁNCHEZ SOTO, S. \& ORTIZ GARCÍA, C.F. 1999. Dos lepidópteros plaga de los pastos en Tabasco, México. Agrociencia (Mexico), 33(1): 51-52.

SANTOS, B.B. 1989. Parasitóides de Mocis latipes (Guenée, 1852) (Lepidoptera: Noctuidae). Arq. Biol. Tecnol., 32(3): 491-494.

SAUER, H.F.G. 1946. Constatação de himenópteros e dípteros entomófagos no Estado de São Paulo. Bol. Fitossanitário, 3: 7-23.

SAUNDERS, J.L., COTO, D. \& KING, A.B.S. 1998. Plagas invertebradas de cultivos anuales alimenticios en America Central. CIAT, Turrialba.

SILVA,A.B., SOUZA, L.A. \& CELESTINOFILHO, P. 1994. Resistência de gramíneas forrageiras ao ataque de Mocis Iatipes (Guen., 1852). Embrapa-CPATU, Belém.

SILVA, A.G.A., GONÇALVES, C.R., GALVÃO, D.M., GONÇALVES, A.J.L., GOMES, J., SILVA, M.M. \& SIMONI, L. 1968. Quarto Catálogo dos insetos que vivem nas plantas do Brasil: seus parasitos e predadores. Parte II, $1^{\circ}$ tomo, Insetos, hospedeiros e inimigos naturais. Ministério da Agricultura, Rio de Janeiro. 
SILVA, R.A. \& CARVALHO, C.F. 1986. Aspectos biológicos de Mocis latipes (Guenée, 1852) (Lepidoptera: Noctuidae) em folhas de milho e arroz em condições de laboratório. Ciênc. Prát., 10: 94-101.

SILVA, R.A., CARVALHO, C.F. \& MATIOLI, J.C. 1991. Efeitos de diferentes dietas na biologia da fase adulta de Mocis latipes (Guenné, 1852) (Lepidoptera: Noctuidae). Pesq. Agropec. Bras., 26(1): 45-50.

SILVAIN, J.-F. 1984. Premières observations sur ecologie de Spodoptera frugiperda (J. E. Smith) et Mocis latipes (Guenée), noctuelles deprédétrices des graminées fourragères en Guyane Française. Prairies guyanaises et elevage bovin. Les Colloques de I'INRA, 24: 243-272.

SILVAIN, J.-F. \& DAUTHUILLE, D. 1985. Le controle des insectes depredateurs des graminees fourrageres en Guyane francaise. 1. La mise en place d'un reseau d'avertissement des attaques de chenilles de noctuelles. Systèmes d'élevage herbager en milieu equatorial. (Hentgen, A. and Girault, N. Eds.), pp. 161-186. Séminaire organisé par le Département de Recherches sur les Systèmes Agraires et le Développement de l'INRA, Cayenne.

SPECHT, A. \& CORSEUIL, E. 2002. Diversidade dos noctuídeos (Lepidoptera, Noctuidae) em Salvador do Sul, RS, Brasil. Rev. Bras. Zool., 19(supl.1): 281-298.

SPECHT, A., SILVA, E.J.E. \& LINK, D. 2004. Noctuídeos (Lepidoptera, Noctuidae) do Museu Entomológico Ceslau Biezanko, Departamento de Fitossanidade, Faculdade de Agronomia "Eliseu Maciel", Universidade Federal de Pelotas, RS. R. Bras. Agrociência, 10(4): 389-409.

SPECHT, A., TESTON, J.A., DI MARE, R.A. \& CORSEUIL, E. 2005. Noctuídeos (Lepidoptera, Noctuidae) coletados em quatro áreas estaduais de conservação do Rio Grande do Sul, Brasil. Rev. Bras. Entomol., 49(1): 130-140.

STRAYER, J.R. 1971. Pasture insect control. Fla. Agric. Ext. Serv. Circ., 292-A: 1-2.

STRÖMBERG, C.A.E. 2011. Evolution of grasses and grassland ecosystems. Annu. Rev. Earth Planet. Sci., 39: 517-544.

TAMIRU, A., KHAN, Z.R. \& BRUCE, T.J.A. 2015. New directions for improving crop resistance to insects by breeding for egg induced defence. Curr. Opin. Insect Sci., 9, 51-55.

TARRAGÓ, M.F.S., CARVALHO, S. \& LINK, D. 1975 Levantamento da família Noctuidae, através de armadilha luminosa, em Santa Maria, RS. Rev. Centro de Ciências Rurais, 5(2): 125-130.
TEIXEIRA, C.A.D. \& TOWNSEND, C.R. 1997. Ocorrência e indicações de controle do Curuquerê dos capinzais (Mocis latipes Guen.) no capim-elefante (Pennisetum purpureum Schum.) em Porto Velho-RO. Embrapa CPAF, Porto Velho [Comunicado técnico $\mathrm{n}^{\circ}$. 135].

TSCHARNTKE, T. \& GREILER, H.J. 1995. Insect communities, grasses, and grasslands. Annu. Rev. Entomol. 40: 535-558.

VERGARA, O., PITRE, H. \& PARVIN, D. 2001. Economic evaluation of lepidopterous pests in intercropped sorghum and maize in southern Honduras. Trop. Agric., 78(3): 190-199.

VICKERY, R.A. 1924. The striped grass looper, Mocis repanda F. in Texas. J. Econ. Entomol., 17(3): 401-405.

VILARINHO, E.C., FERNANDES, O.A., HUNT, T.E. AND CAIXETA, D.F. 2011. Movement of Spodoptera frugiperda adults (Lepidoptera: Noctuidae) in maize in Brazil. Fla. Entomol., 94(3): 480-488.

VILELA, L., MARTHA JR., G.B., MACEDO, M.C.M., MARCHÃO, R.L., GUIMARÃES JR., R., PULROLNIK, K. \& MACIEL, G.A. 2011. Sistemas de integração lavourapecuária na região do Cerrado. Pesq. Agropec. Bras., 46(10): 1127-1138.

WAGNER, D.L., SCHWEITZER, D.F., SULLIVAN, J.B. \& REARDON, R.C. 2011. Owlet Caterpillars of Eastern North America. Princeton University Press, Princeton

WARE, F.L. 1973. Insect pests on ornamentals. Tri-ology Technical Report, 12(10): 2.

WATSON, J.R. 1933. An outbreak of Mocis repanda Fabr. Fla. Entomol., 17(1): 15.

WHITAKER Jr., J.O., BROOKS, M., SCOTT, L., FINN, L.S. \& SMITH, C.L. 2007. Food habits of rafinesque's big-eared bat from Florida. Fla. Sci., 70(3): 202-206.

WOLCOTT, G.N. 1921. The minor sugar-cane insects of Porto Rico. Journal of the Dept. Agric. Puerto Rico, 5: 5-46.

ZENKER, M.M., BOTTON, M., TESTON, J.A. \& SPECHT, A. 2010. Noctuidae moths occurring in grape orchards in Serra Gaúcha, Brazil and their relation to fruit-piercing. Rev. Bras. Entomol., 54(2): 288-297.

Received: $27 / 08 / 2020$

Revised: 23/12/2020

Accepted: 04/01/2021

Published online: 12/02/2021 